\title{
Solubility of rare earth metal bromides and iodides in aqueous systems
}

\author{
Cezary Gumiński • Heidelore Voigt • \\ Dewen Zeng
}

Received: 26 October 2010/Accepted: 2 February 2011/Published online: 1 March 2011

(C) The Author(s) 2011. This article is published with open access at Springerlink.com

\begin{abstract}
The International Union of Pure and Applied Chemistry (IUPAC) project of collection, compilation, and critical evaluation of solubility data of bromides and iodides of the scandium group and all lanthanides in water and aqueous systems containing either halide acids, halide salts, or organic compounds is under preparation. As a result of their similarity to the chlorides, which were recently evaluated, the bromides and iodides in the lanthanide series should show some regularities in their solubility data. Unfortunately, the corresponding results show a large scatter when ordered according to the atomic number. Thus, it is complicated to select the best data for recommendation. Reasons for the inaccuracy of solubility measurements are outlined. In fact some solubility values of bromides predicted by correlation with chlorides seem to be more reliable than the experimental ones. As sufficient experimental data at various temperatures were available,
\end{abstract}

This paper was orally presented during the 14 th International Symposium on Solubility Phenomena, 25-30 July, 2010, Leoben, Austria.

\section{Gumiński (ه)}

Department of Chemistry, University of Warsaw,

Pasteura 1, 02093 Warsaw, Poland

e-mail: cegie@chem.uw.edu.pl

H. Voigt

Institut f. Anorganische Chemie, TU Bergakademie Freiberg,

Leipziger Str. 29, Freiberg 09596, Germany

D. Zeng

College of Chemistry and Chemical Engineering,

Central South University, Changsha 410083,

People's Republic of China the water-rich fragment of the $\mathrm{LaBr}_{3}-\mathrm{H}_{2} \mathrm{O}$ equilibrium phase diagram has been formed and depicted. It seems to be similar to the well-known $\mathrm{LaCl}_{3}-\mathrm{H}_{2} \mathrm{O}$ diagram. Several regularities, with respect to stoichiometry and solubility of compounds formed, were observed during investigations of the aqueous ternary systems. The complex iodides of various lanthanides display more regularities in their properties than the bromides do.

Keywords Phase diagrams - Thermochemistry . Hydrates - Solubility · Rare earth metal bromides . Rare earth metal iodides

\section{Introduction}

This is a brief assessment which is a continuation of the critical evaluation of solubilities of rare earth metal halides in water-containing systems. The part on solubilities of chlorides was already published [1-3]. It would seem that bromides and iodides of rare earth metals are less significant than chlorides. However, running through Chemical Abstracts one may find plenty of contemporarily important applications of these compounds in technology and science: for production of alloys and compounds, as catalysts in organic synthesis and polymerization, as corrosion inhibitors, as converting materials for various kinds of spectroscopy, as lighting and laser materials, as solid electrolytes for lithium batteries, and as dyes for glass, ceramics, and ink. Investigation of the solubility equilibria in ternary and multicomponent systems is useful for the detection of eventual formation of double salts, complex compounds, and solid solutions of the hydrates. The knowledge about such systems may improve the extraction and refining processes of rare earth metals. 


\section{Solubility data for rare earth metal bromides and iodides in water}

Although a number of solubility studies of rare earth metal bromides and iodides were published, there is no systematic critical evaluation of these results so far. The first step of such a procedure after the data collection is an estimation of experimental precision and accuracy. Unfortunately, this information was seldom available in the papers. In the case of bromides, the laboratories of $\mathrm{Ni}$ shimura et al. [4] and Voigt [5] achieved precision in some experiments of $\pm 0.1 \%$ and in the laboratory of Qiao et al. [6] it was specified as $\pm 0.2 \%$. The rest of the laboratories did not report any uncertainties and we estimate that the precision was then $\pm(1-5) \%$. In the case of iodides, the laboratory of Alikberova specified the precision as $\pm 0.2 \%$ [7] or even $\pm 0.05 \%$ [8], but in this case we prefer a less optimistic estimate of $\pm 0.5 \%$, and we appraise that precision in other laboratories, which did not specify it, was $\pm(1-5) \%$.

We selected the most reliable values from the existing solubility data collection [9] for the bromides and iodides and they are presented in Fig. 1. For comparison, Fig. 1 also contains the recommended values of the solubility of rare earth metal chlorides at $298.2 \mathrm{~K}$ [1-3]. These values are precisely known within $\pm 0.1 \%$, and therefore they may be used as the reference data basis.

If one intends to follow the solubility changes with regard to the atomic number (or ionic radius) of the rare earth metal one should compare the solute salts which possess the same stoichiometry and crystal structure of its hydrate. Concerning the chlorides one observes two parabola-like curves: the first one being placed between La and $\operatorname{Pr}$ chlorides when the equilibrium solid phase is

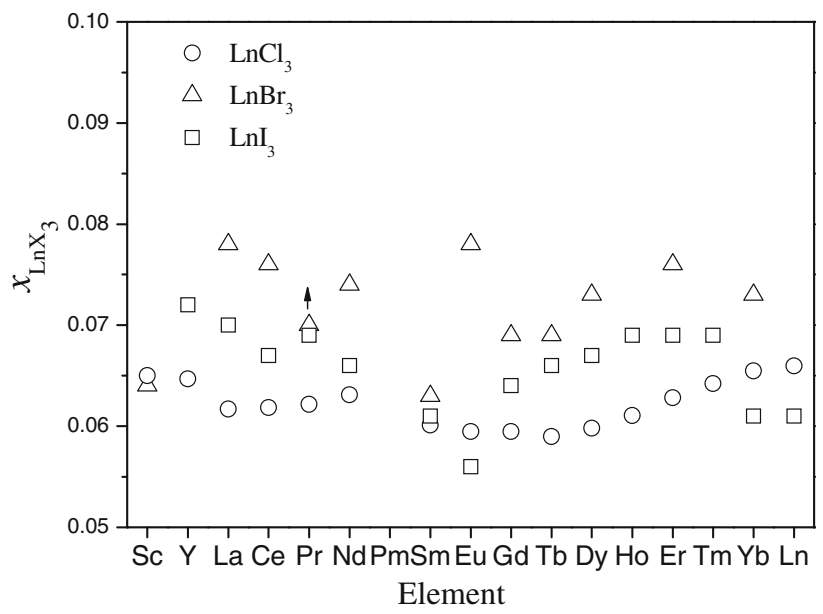

Fig. 1 Selected solubilities of rare earth metal halides $\mathrm{LnX}_{3}$ in $\mathrm{H}_{2} \mathrm{O}$ : $\mathrm{LnBr}_{3}$ at 298 or $303 \mathrm{~K}$ (triangles), $\mathrm{LnI}_{3}$ at $273 \mathrm{~K}$ (squares), and $\mathrm{LnCl}_{3}$ (recommended values) at $298.2 \mathrm{~K}$ (circles) isostructural triclinic $\mathrm{LnCl}_{3} \cdot 7 \mathrm{H}_{2} \mathrm{O}$ and the second one extending between $\mathrm{Nd}$ and $\mathrm{Lu}$ (including also $\mathrm{Y}$ ) when the equilibrium solid phase is isostructural monoclinic $\mathrm{LnCl}_{3} \cdot 6 \mathrm{H}_{2} \mathrm{O}$ [1]. As a result of their similarity to the chlorides, the bromides form the isostructural triclinic $\mathrm{LnBr}_{3} \cdot 7 \mathrm{H}_{2} \mathrm{O}$ phase for $\mathrm{La}, \mathrm{Ce}$, and $\mathrm{Pr}$ and the isostructural monoclinic $\mathrm{LnBr}_{3} \cdot 6 \mathrm{H}_{2} \mathrm{O}$ phase for lanthanides between $\mathrm{Nd}$ and $\mathrm{Yb}$. However, there are contradictory opinions about the stoichiometry of the equilibrium solid phase for the range $\mathrm{Ho}$ to $\mathrm{Lu}$; it is either the isostructural monoclinic $\mathrm{LnBr}_{3} \cdot 6 \mathrm{H}_{2} \mathrm{O}$ or monoclinic $\mathrm{LnBr}_{3} \cdot 8 \mathrm{H}_{2} \mathrm{O}$ phase [9-12]. In the case of iodides, isostructural orthorhombic $\mathrm{LnI}_{3} \cdot 9 \mathrm{H}_{2} \mathrm{O}$ was identified for the lanthanide range of $\mathrm{La}$ to $\mathrm{Er}$ and isostructural monoclinic $\mathrm{LnI}_{3} \cdot 8 \mathrm{H}_{2} \mathrm{O}$ for the range of $\mathrm{Tm}$ to $\mathrm{Lu}$ [10]; however, different ranges of the solid solute existence were reported $[11,12]$. It is a well-known fact that structures and stoichiometries of $\mathrm{YBr}_{3}$ and $\mathrm{YI}_{3}$ hydrates resemble those typical for lanthanides, but crystals of $\mathrm{ScBr}_{3}$ and $\mathrm{ScI}_{3}$ hydrates are dissimilar compared with the corresponding lanthanide compounds.

The segments of the curve for chlorides in Fig. 1 are quite smooth; the solubility changes gradually reach the minimum at $\mathrm{TbCl}_{3}$. In the case of bromides the scatter of the selected solubilities is significant (up to 20\%). Thus, the expected similarity between the chloride and bromide's solubility dependence on the atomic number is blurred. Because the mean molal activity coefficients of concentrated solutions [13], the enthalpies of formation of the hydrates, and their dehydration and lattice energies for the isostructural bromides as well as chlorides change smoothly with the rare earth metal atomic number [14], the reliable solubility results for the bromides should form a parallel-like curve moved a fraction up in comparison to the chlorides' curve. On the basis of this assumption, we feel empowered to predict the solubilities of the bromides more reliably than they were determined. The predicted solubilities for the bromides from $\mathrm{Nd}$ to $\mathrm{Yb}$, which form hexahydrates, at about $300 \mathrm{~K}$, are collected in Table 1.

The predicted values were obtained by the addition of $\Delta x=0.009$ to the recommended mol fraction values for chlorides [1-3]; the value 0.009 is the mean difference of the solubility data between all bromides and chlorides. Thus, the parabola-like curve for the chlorides has been moved up by $\Delta x=0.009$ on the mol fraction scale to predict the solubility of bromides. We are convinced that our predictive values are more reliable than the very scattered experimental data. As was shown in the case of $\mathrm{LaBr}_{3}$ the temperature dependence of the solubility near $300 \mathrm{~K}$ is very small, about 0.0002 in mol fraction per $\mathrm{K}$; therefore the difference of temperatures in Table 1 is not essential in such predictions. If in the range $\mathrm{Ho}$ to $\mathrm{Yb}$ the equilibrium solid phase at about $300 \mathrm{~K}$ is of $\mathrm{LnBr}_{3} \cdot 8 \mathrm{H}_{2} \mathrm{O}$ type then the predicted solubility values for the bromides of 
Table 1 Selected experimental and predicted solubility of $\mathrm{LnBr}_{3}$ in $\mathrm{H}_{2} \mathrm{O}$ at about $300 \mathrm{~K}$ when the equilibrium solid phase was isostructural $\mathrm{LnBr}_{3} \cdot 6 \mathrm{H}_{2} \mathrm{O}$

\begin{tabular}{lllllll}
\hline Salt & $T(\mathrm{~K})$ & $x_{1}$ (experimental) & $x_{1}$ (predicted) & Salt & $T(\mathrm{~K})$ & $x_{1}($ recommended) \\
\hline $\mathrm{NdBr}_{3}$ & 303 & 0.074 & 0.075 & $\mathrm{NdCl}_{3}$ & 298.2 & 0.066 \\
$\mathrm{PmBr}_{3}$ & 300 & - & 0.073 & $\mathrm{PmCl}_{3}$ & 298.2 & 0.064 \\
$\mathrm{SmBr}_{3}$ & 303 & 0.063 & 0.071 & $\mathrm{SmCl}_{3}$ & 298.2 & 0.062 \\
$\mathrm{EuBr}_{3}$ & 298 & 0.078 & 0.070 & $\mathrm{EuCl}_{3}$ & 298.2 & 0.061 \\
$\mathrm{GdBr}_{3}$ & 298 & 0.069 & 0.070 & $\mathrm{GdCl}_{3}$ & 298.2 & 0.061 \\
$\mathrm{TbBr}_{3}$ & 303 & 0.069 & 0.069 & $\mathrm{TbCl}_{3}$ & 298.2 & 0.060 \\
$\mathrm{DyBr}_{3}$ & 298 & 0.073 & 0.070 & $\mathrm{DyCl}_{3}$ & 298.2 & 0.061 \\
$\mathrm{HoBr}_{3}$ & 300 & - & 0.071 & $\mathrm{HoCl}_{3}$ & 298.2 & 0.062 \\
$\mathrm{ErBr}_{3}$ & 303 & 0.076 & 0.073 & $\mathrm{ErCl}_{3}$ & 298.2 & 0.064 \\
$\mathrm{TmBr}_{3}$ & 300 & - & 0.074 & $\mathrm{TmCl}_{3}$ & 298.2 & 0.065 \\
$\mathrm{YbBr}_{3}$ & 303 & 0.073 & 0.076 & $\mathrm{YbCl}_{3}$ & 298.2 & 0.067
\end{tabular}

The predicted values were obtained by addition of 0.009 to the recommended solubilities of $\mathrm{LnCl}_{3}$ in $\mathrm{H}_{2} \mathrm{O}$ at $298.2 \mathrm{~K}$ from Mioduski et al. [1-3]

these elements in Table 1 will be invalid. A similar procedure may be proposed for the bromides of La-Pr which form heptahydrates; however, the only reliable value of the solubility is known for $\mathrm{LaBr}_{3}$.

Because most of the chlorides and iodides form different crystal structures and there are less thermodynamic data for the iodides (the enthalpies of formation and dissolution of $\mathrm{LnI}_{3}$ in water both exhibit a smooth dependence on the atomic number with a small break at Gd [15]) a similar prediction procedure for the iodide solubilities would be premature; however, the solubility changes in the rare earth metal iodides row between $\mathrm{La}$ and $\mathrm{Eu}$ should be distinctly more smooth than that experimentally observed, and probably the solubility minimum value for $\mathrm{EuI}_{3}$ is fortuitous.

It seems that there are several causes of the uncertainties of the solubility data. The equilibria between solids and aqueous solutions in these systems are reached after a very long time. This phenomenon proceeds along with a strong tendency toward oversaturation. The solubilities of $\mathrm{LnBr}_{3}$ and $\mathrm{LnI}_{3}$ depend explicitly on $\mathrm{pH}$ in the saturated solutions which is exemplified best by the investigation of the $\mathrm{Ho}_{2} \mathrm{O}_{3}$ solubility in $\mathrm{HI}$ solution [16]. When $\mathrm{Ho}_{2} \mathrm{O}_{3}$ and $\mathrm{HI}$ were taken in stoichiometric ratio (1:6) to form $\mathrm{HoI}_{3}$ then solubility of this salt reached the highest value. When $\mathrm{Ho}_{2} \mathrm{O}_{3}$ was in excess then the less soluble $\mathrm{Ho}_{2} \mathrm{I}(\mathrm{OH})_{5}$ salt was formed, this may be interpreted as the following hydrolysis reaction:

$2 \mathrm{HoI}_{3}+5 \mathrm{H}_{2} \mathrm{O} \rightleftharpoons \mathrm{Ho}_{2} \mathrm{I}(\mathrm{OH})_{5}+5 \mathrm{HI}$

When $\mathrm{HI}$ was in excess relative to $\mathrm{Ho}_{2} \mathrm{O}_{3}$ then the solubility of $\mathrm{HoI}_{3}$ clearly decreased, presumably due to the common ion effect. Therefore, the proper $\mathrm{pH}$ of the solution and the correct stoichiometry of the salt $\mathrm{LnI}_{3}$ should be strictly controlled because only then is its solubility the highest. Complexation of the rare earth ions with an excess of either $\mathrm{Br}^{-}$or $\mathrm{I}^{-}$, separately, is rather weak in the corresponding solutions [17]; however, as was shown during the investigations of ternary systems with other halide salts, double salts may be formed in the corresponding ternary systems. It is sure that the investigations of the iodides must be performed in an oxygenfree atmosphere to avoid decomposition of the iodides and subsequent iodine evolution. Hence, the solubility measurements of the iodides were preferably performed at $273 \mathrm{~K}$ and quite seldom at higher temperatures. Likewise, during careful observations of the bromides during the experiments we have noticed a light bronzing of the samples which may mean that the analogous oxidation of bromides may also occur. There are the special cases of $\mathrm{EuI}_{3}$ and $\mathrm{YbI}_{3}$ which due to the dismutation-like reactions form quite stable salts in their divalent state with an evolution of either $\mathrm{Br}_{2}$ or $\mathrm{I}_{2}$, probably also influencing the solubility determinations. Unfortunately, the solubilities of the divalent bromides and iodides were not determined but these salts also seem to have good solubility.

It appears that the method of experimental determination of solubility plays a secondary role in the uncertainty of the results because, quite frequently, the values obtained in one laboratory also showed drastic differences for analogous systems of the neighboring rare earth elements. The following methods of analysis of the saturated solutions have been used: titration of Ln ions with EDTA solution, spectrophotometric determination in the case of simultaneous analysis of two Ln metals, precipitation of Ln oxalate with ignition to $\mathrm{Ln}_{2} \mathrm{O}_{3}$ and weighing, an oxidimetric titration in the case of $\mathrm{Ce}$, argentometric titration of $\mathrm{Br}$ or $\mathrm{I}$ ions (sometimes with the potentiometric detection of equivalent point), and precipitation of $\mathrm{AgI}$ and weighing. Exceptionally, the isopiestic technique was used in the case of $\mathrm{ScBr}_{3}$ solubility determination and some differential scanning calorimetry (DSC) experiments were performed for $\mathrm{LaBr}_{3}$ 
[9]. If either the Ln or the $\mathrm{Br}$ (or I) content was analyzed only whereas the stoichiometry of a salt was not precisely checked then the possibility of erroneousness of the solubility determination increased.

When the solubility experiments are extended to higher temperatures then one will be faced with some experimental difficulties due to the hydrolysis reaction written schematically for bromides:

$\mathrm{LnBr}_{3}+\mathrm{H}_{2} \mathrm{O} \rightleftharpoons \mathrm{LnOBr}+2 \mathrm{HBr}$

The use of a high pressure and acid-resistant apparatus is indispensable under such experimental conditions. Because the undesirable reaction (2) is a moderately fast process it is suggested to perform a short thermal analysis run rather than an extended solubility equilibration.

Probably due to the mentioned difficulties, the solubility determinations at higher temperatures were only effectively performed for the $\mathrm{LaBr}_{3}-\mathrm{H}_{2} \mathrm{O}$ system with the use of chemical analysis of the equilibrated phases as well as some complementary DSC measurements [5]. The solubility results obtained for this system between 298 and $393 \mathrm{~K}$ allowed one to formulate the proper solubility equation. As was observed in the case of many chloride systems [1-3], the experimental values of $\mathrm{LaBr}_{3}$ solubility in water collected in Table 2 do not fit, and they should not fit, to the simple linear equation:

$\ln x_{1}=A+B T^{-1}$

which can be valid for non-electrolyte solutions. On the left-hand side of Eq. 3, the ionic mol fractions [18] should be taken into account.

Therefore, the following equation, used by the IUPAC Subcommittee on Solubility and Equilibrium Data [19, 20], was taken into account:

$$
\begin{aligned}
& \ln \left\{x_{1}^{v}\left(1-x_{1}\right)^{r}(v+r)^{v+r} r^{-r}\left[1+(v-1) x_{1}\right]^{-(v+r)}\right\} \\
& \quad=A+B T^{-1}+C \ln T+D T
\end{aligned}
$$

where $x_{1}$ is the solubility of the salt expressed in mol fractions, $T$ the absolute temperature in $\mathrm{K}, v$ the number of ions produced upon salt dissociation, $r$ the number of solvent molecules in the formula of the solid solvate equilibrated. The constants $A, B, C$, and $D$ can be derived from a fitting procedure if more than four solubility results are at our disposal, and $r$ and $v$ are known from other experiments. Thus, the following solubility equation was obtained by fitting to the solubility data (from Table 2) for $\mathrm{LaBr}_{3} \cdot 7 \mathrm{H}_{2} \mathrm{O}$ in the temperature range $298-389.6 \mathrm{~K}$ :

$$
\begin{aligned}
\ln & \left\{x_{1}^{4}\left(1-x_{1}\right)^{7}(4+7)^{4+7} 7^{-7}\left[1+(4-1) x_{1}\right]^{-(4+7)}\right\} \\
= & 515.5885-14,145.966 T^{-1} \\
& \quad-89.79261 \ln T+0.14468 T
\end{aligned}
$$

\begin{tabular}{|c|c|c|c|c|}
\hline$T(\mathrm{~K})$ & $m_{1}$ & $x_{1}$ & Equilibrium solid phase & References \\
\hline 258 & 4.28 & 0.0714 & $?$ & This work \\
\hline 265 & 4.30 & 0.0718 & $?$ & This work \\
\hline 266 & 4.32 & 0.0721 & $?$ & This work \\
\hline 270 & 4.46 & 0.0744 & $?$ & This work \\
\hline 270 & 4.46 & 0.0744 & $?$ & This work \\
\hline 288 & 4.463 & 0.07442 & $\mathrm{LaBr}_{3} \cdot 8 \mathrm{H}_{2} \mathrm{O}$ & {$[26]$} \\
\hline \multirow[t]{5}{*}{298} & 4.52 & 0.07530 & $\mathrm{LaBr}_{3} \cdot 9 \mathrm{H}_{2} \mathrm{O}$ (estimated) & {$[27]$} \\
\hline & 4.800 & 0.07959 & $\mathrm{LaBr}_{3} \cdot 7 \mathrm{H}_{2} \mathrm{O}$ & {$[5]$} \\
\hline & 4.822 & 0.07992 & $\mathrm{LaBr}_{3} \cdot 7 \mathrm{H}_{2} \mathrm{O}$ & {$[5]$} \\
\hline & 4.654 & 0.07818 & $\mathrm{LaBr}_{3} \cdot 7 \mathrm{H}_{2} \mathrm{O}$ & {$[5]$} \\
\hline & 4.708 & 0.07818 & $\mathrm{LaBr}_{3} \cdot 7 \mathrm{H}_{2} \mathrm{O}$ & {$[5]$} \\
\hline 298.2 & 4.76 & 0.0790 & $\mathrm{LaBr}_{3} \cdot 9 \mathrm{H}_{2} \mathrm{O}(?)$ & {$[4]$} \\
\hline \multirow[t]{5}{*}{303} & 4.461 & 0.07439 & $\mathrm{LaBr}_{3} \cdot 8 \mathrm{H}_{2} \mathrm{O}$ & {$[28]$} \\
\hline & 4.5 & 0.075 & $\mathrm{LaBr}_{3} \cdot 8 \mathrm{H}_{2} \mathrm{O}$ & [29] \\
\hline & 4.696 & 0.07800 & $\mathrm{LaBr}_{3} \cdot 8 \mathrm{H}_{2} \mathrm{O}$ & {$[26]$} \\
\hline & 4.812 & 0.07977 & - & {$[5]$} \\
\hline & 4.767 & 0.07908 & - & {$[5]$} \\
\hline \multirow[t]{4}{*}{308} & 4.742 & 0.07870 & $\mathrm{LaBr}_{3} \cdot 7 \mathrm{H}_{2} \mathrm{O}$ & {$[5]$} \\
\hline & 4.679 & 0.07774 & $\mathrm{LaBr}_{3} \cdot 7 \mathrm{H}_{2} \mathrm{O}$ & {$[5]$} \\
\hline & 4.751 & 0.07884 & $\mathrm{LaBr}_{3} \cdot 7 \mathrm{H}_{2} \mathrm{O}$ & {$[5]$} \\
\hline & 4.793 & 0.07948 & $\mathrm{LaBr}_{3} \cdot 7 \mathrm{H}_{2} \mathrm{O}$ & {$[5]$} \\
\hline \multirow[t]{2}{*}{313} & 4.885 & 0.08088 & - & {$[5]$} \\
\hline & 4.836 & 0.08010 & - & {$[5]$} \\
\hline \multirow[t]{2}{*}{318} & 4.982 & 0.08236 & $\mathrm{LaBr}_{3} \cdot 7 \mathrm{H}_{2} \mathrm{O}$ & {$[5]$} \\
\hline & 4.936 & 0.08166 & $\mathrm{LaBr}_{3} \cdot 7 \mathrm{H}_{2} \mathrm{O}$ & {$[5]$} \\
\hline \multirow[t]{4}{*}{323} & 5.293 & 0.08705 & - & {$[5]$} \\
\hline & 5.208 & 0.08577 & - & {$[5]$} \\
\hline & 4.900 & 0.08111 & $\mathrm{LaBr}_{3} \cdot 7 \mathrm{H}_{2} \mathrm{O}$ & {$[5]$} \\
\hline & 4.903 & 0.08116 & $\mathrm{LaBr}_{3} \cdot 7 \mathrm{H}_{2} \mathrm{O}$ & {$[5]$} \\
\hline \multirow[t]{2}{*}{328} & 5.103 & 0.08419 & $\mathrm{LaBr}_{3} \cdot 7 \mathrm{H}_{2} \mathrm{O}$ & {$[5]$} \\
\hline & 5.079 & 0.08383 & $\mathrm{LaBr}_{3} \cdot 7 \mathrm{H}_{2} \mathrm{O}$ & {$[5]$} \\
\hline \multirow[t]{5}{*}{333} & 4.996 & 0.08257 & $\mathrm{LaBr}_{3} \cdot 7 \mathrm{H}_{2} \mathrm{O}$ & {$[5]$} \\
\hline & 5.004 & 0.08269 & $\mathrm{LaBr}_{3} \cdot 7 \mathrm{H}_{2} \mathrm{O}$ & {$[5]$} \\
\hline & 5.090 & 0.08399 & $\mathrm{LaBr}_{3} \cdot 7 \mathrm{H}_{2} \mathrm{O}$ & {$[5]$} \\
\hline & 4.963 & 0.08207 & $\mathrm{LaBr}_{3} \cdot 7 \mathrm{H}_{2} \mathrm{O}$ & {$[5]$} \\
\hline & 4.996 & 0.08257 & $\mathrm{LaBr}_{3} \cdot 7 \mathrm{H}_{2} \mathrm{O}$ & {$[5]$} \\
\hline \multirow[t]{2}{*}{338} & 5.219 & 0.08594 & $\mathrm{LaBr}_{3} \cdot 7 \mathrm{H}_{2} \mathrm{O}$ & {$[5]$} \\
\hline & 5.120 & 0.08445 & $\mathrm{LaBr}_{3} \cdot 7 \mathrm{H}_{2} \mathrm{O}$ & {$[5]$} \\
\hline \multirow[t]{3}{*}{343} & 5.271 & 0.08672 & $\mathrm{LaBr}_{3} \cdot 7 \mathrm{H}_{2} \mathrm{O}$ & {$[5]$} \\
\hline & 5.186 & 0.08544 & $\mathrm{LaBr}_{3} \cdot 7 \mathrm{H}_{2} \mathrm{O}$ & {$[5]$} \\
\hline & 5.242 & 0.08629 & $\mathrm{LaBr}_{3} \cdot 7 \mathrm{H}_{2} \mathrm{O}$ & {$[5]$} \\
\hline \multirow[t]{4}{*}{348} & 5.190 & 0.08550 & $\mathrm{LaBr}_{3} \cdot 7 \mathrm{H}_{2} \mathrm{O}$ & {$[5]$} \\
\hline & 5.224 & 0.08601 & $\mathrm{LaBr}_{3} \cdot 7 \mathrm{H}_{2} \mathrm{O}$ & {$[5]$} \\
\hline & 5.168 & 0.08517 & $\mathrm{LaBr}_{3} \cdot 7 \mathrm{H}_{2} \mathrm{O}$ & {$[5]$} \\
\hline & 5.131 & 0.08461 & $\mathrm{LaBr}_{3} \cdot 7 \mathrm{H}_{2} \mathrm{O}$ & {$[5]$} \\
\hline \multirow[t]{2}{*}{353} & 5.483 & 0.08990 & $\mathrm{LaBr}_{3} \cdot 7 \mathrm{H}_{2} \mathrm{O}$ & {$[5]$} \\
\hline & 5.462 & 0.08958 & $\mathrm{LaBr}_{3} \cdot 7 \mathrm{H}_{2} \mathrm{O}$ & {$[5]$} \\
\hline
\end{tabular}

Table 2 Experimental solubilities of $\mathrm{LaBr}_{3}$ in $\mathrm{H}_{2} \mathrm{O}$ at various temperatures 
Table 2 continued

\begin{tabular}{|c|c|c|c|c|}
\hline$T(\mathrm{~K})$ & $m_{1}$ & $x_{1}$ & Equilibrium solid phase & References \\
\hline \multirow[t]{2}{*}{358} & 5.620 & 0.09194 & $\mathrm{LaBr}_{3} \cdot 7 \mathrm{H}_{2} \mathrm{O}$ & {$[5]$} \\
\hline & 5.670 & 0.09268 & $\mathrm{LaBr}_{3} \cdot 7 \mathrm{H}_{2} \mathrm{O}$ & {$[5]$} \\
\hline \multirow[t]{2}{*}{363} & 5.833 & 0.09509 & $\mathrm{LaBr}_{3} \cdot 7 \mathrm{H}_{2} \mathrm{O}$ & {$[5]$} \\
\hline & 5.759 & 0.09400 & $\mathrm{LaBr}_{3} \cdot 7 \mathrm{H}_{2} \mathrm{O}$ & {$[5]$} \\
\hline \multirow[t]{4}{*}{368} & 5.812 & 0.09478 & $\mathrm{LaBr}_{3} \cdot 7 \mathrm{H}_{2} \mathrm{O}$ & {$[5]$} \\
\hline & 5.846 & 0.09528 & $\mathrm{LaBr}_{3} \cdot 7 \mathrm{H}_{2} \mathrm{O}$ & {$[5]$} \\
\hline & 5.830 & 0.09504 & $\mathrm{LaBr}_{3} \cdot 7 \mathrm{H}_{2} \mathrm{O}$ & {$[5]$} \\
\hline & 5.866 & 0.09557 & $\mathrm{LaBr}_{3} \cdot 7 \mathrm{H}_{2} \mathrm{O}$ & {$[5]$} \\
\hline \multirow[t]{2}{*}{373} & 6.178 & 0.10015 & $\mathrm{LaBr}_{3} \cdot 7 \mathrm{H}_{2} \mathrm{O}$ & {$[5]$} \\
\hline & 6.179 & 0.10016 & $\mathrm{LaBr}_{3} \cdot 7 \mathrm{H}_{2} \mathrm{O}$ & {$[5]$} \\
\hline \multirow[t]{2}{*}{378} & 6.370 & 0.1029 & $\mathrm{LaBr}_{3} \cdot 7 \mathrm{H}_{2} \mathrm{O}$ & {$[5]$} \\
\hline & 6.461 & 0.1043 & $\mathrm{LaBr}_{3} \cdot 7 \mathrm{H}_{2} \mathrm{O}$ & {$[5]$} \\
\hline \multirow[t]{4}{*}{383} & 6.742 & 0.1083 & $\mathrm{LaBr}_{3} \cdot 7 \mathrm{H}_{2} \mathrm{O}$ & {$[5]$} \\
\hline & 6.783 & 0.1089 & $\mathrm{LaBr}_{3} \cdot 7 \mathrm{H}_{2} \mathrm{O}$ & {$[5]$} \\
\hline & 8.580 & 0.1339 & $?$ & {$[5]$} \\
\hline & 8.691 & 0.1354 & $?$ & {$[5]$} \\
\hline \multirow[t]{4}{*}{388} & 8.142 & 0.1279 & $\mathrm{LaBr}_{3} \cdot 7 \mathrm{H}_{2} \mathrm{O}$ & {$[5]$} \\
\hline & 8.159 & 0.1281 & $\mathrm{LaBr}_{3} \cdot 7 \mathrm{H}_{2} \mathrm{O}$ & {$[5]$} \\
\hline & 9.994 & 0.1526 & $\mathrm{LaBr}_{3} \cdot 3 \mathrm{H}_{2} \mathrm{O}$ & {$[5]$} \\
\hline & 10.128 & 0.1543 & $\mathrm{LaBr}_{3} \cdot 3 \mathrm{H}_{2} \mathrm{O}$ & {$[5]$} \\
\hline 389.6 & - & 0.1250 & $\mathrm{LaBr}_{3} \cdot 7 \mathrm{H}_{2} \mathrm{O}$ & {$[5]$} \\
\hline 390.7 & 10.042 & 0.1532 & $\mathrm{LaBr}_{3} \cdot 3 \mathrm{H}_{2} \mathrm{O}$ & {$[5]$} \\
\hline 393 & 10.360 & 0.1573 & $\mathrm{LaBr}_{3} \cdot 3 \mathrm{H}_{2} \mathrm{O}$ & {$[5]$} \\
\hline
\end{tabular}

In other systems, the corresponding solubility data were either not reliable (as for the $\mathrm{YBr}_{3}-\mathrm{H}_{2} \mathrm{O}$ ) or a considerable part of the data related to different equilibrium phases (as for the $\mathrm{LaI}_{3}-\mathrm{H}_{2} \mathrm{O}$ system) and then Eq. 4 loses its validity.

\section{Phase diagrams at the water-rich side}

Concerning the composition of equilibrium phases at higher temperatures, the thermogravimetric technique in connection with differential thermal analysis (DTA) (or DSC) was found to be very informative. It was well proved for $\mathrm{LaBr}_{3} \cdot 7 \mathrm{H}_{2} \mathrm{O}$ that with an increase of temperature the following dehydration stages were observed:

$$
\begin{aligned}
\mathrm{LaBr}_{3} \cdot 7 \mathrm{H}_{2} \mathrm{O} & \rightarrow \mathrm{LaBr}_{3} \cdot 3 \mathrm{H}_{2} \mathrm{O} \rightarrow \mathrm{LaBr}_{3} \cdot \mathrm{H}_{2} \mathrm{O} \rightarrow \mathrm{LaBr}_{3} \\
& \rightarrow \mathrm{LaOBr} \rightarrow \mathrm{La}_{2} \mathrm{O}_{3}
\end{aligned}
$$

This behavior is distinctly reflected in the experimental run shown in Fig. 2. The similar dehydration scheme may be also proposed for $\mathrm{CeBr}_{3} \cdot 7 \mathrm{H}_{2} \mathrm{O}$ and $\mathrm{PrBr}_{3} \cdot 7 \mathrm{H}_{2} \mathrm{O}$.

The observed scheme for the bromide hexahydrates of heavier lanthanides was simpler, as it is exemplarily shown for $\mathrm{SmBr}_{3} \cdot 6 \mathrm{H}_{2} \mathrm{O}$ :

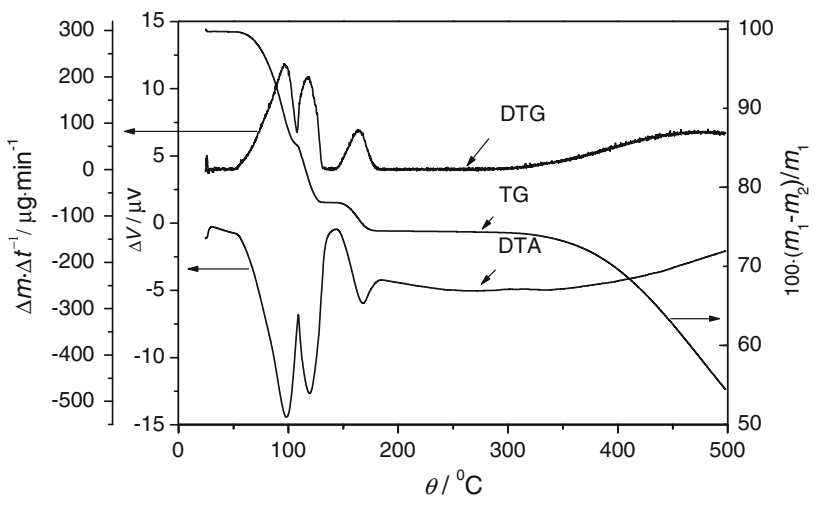

Fig. $2 T G$ thermogravimetric [as relative mass decrement, $\left(m_{1}-\right.$ $\left.\left.m_{2}\right) / m_{1}\right], T D G$ differential thermogravimetric [as mass decrement in time, $(\Delta m / \Delta t)]$, and DTA differential thermal analysis (as voltage difference between thermocouple legs, $V$ ) curves of $\mathrm{LaBr}_{3} \cdot 7 \mathrm{H}_{2} \mathrm{O}$. The experiment was performed on a DTA/TG SSC 5200 (Seiko Instruments), with a heating rate $5 \mathrm{~K} / \mathrm{min}$, in a $\mathrm{Pt}$ crucible, in $\mathrm{Ar}$ atmosphere

$$
\begin{aligned}
\mathrm{SmBr}_{3} \cdot 6 \mathrm{H}_{2} \mathrm{O} & \rightarrow \mathrm{SmBr}_{3} \cdot \mathrm{H}_{2} \mathrm{O} \rightarrow \mathrm{SmBr}_{3} \rightarrow \mathrm{SmOBr} \\
& \rightarrow \mathrm{Sm}_{2} \mathrm{O}_{3}
\end{aligned}
$$

However, as a result of its similarity to the chlorides [1-3], the bromide should also be able to form $\mathrm{SmBr}_{3} \cdot 3 \mathrm{H}_{2} \mathrm{O}$ at a slower heating rate than that applied by Mayer and Zolotov [21]. Consequently, one may predict that the phase diagrams of other $\mathrm{LnBr}_{3}-\mathrm{H}_{2} \mathrm{O}$ systems should be similar in the form of the liquidus shape, composition, and stability of the equilibrium solid phases (types of the hydrates).

Likewise, the lighter Ln iodides dehydrate gradually according to the following reaction chain:

$$
\operatorname{PrI}_{3} \cdot 9 \mathrm{H}_{2} \mathrm{O} \rightarrow \operatorname{Pr} \mathrm{I}_{3} \cdot 6 \mathrm{H}_{2} \mathrm{O} \rightarrow \operatorname{PrI}_{3} \cdot 3 \mathrm{H}_{2} \mathrm{O} \rightarrow \operatorname{PrI}_{3}
$$$$
\rightarrow \mathrm{PrOI} \rightarrow \mathrm{Pr}_{2} \mathrm{O}_{3}
$$

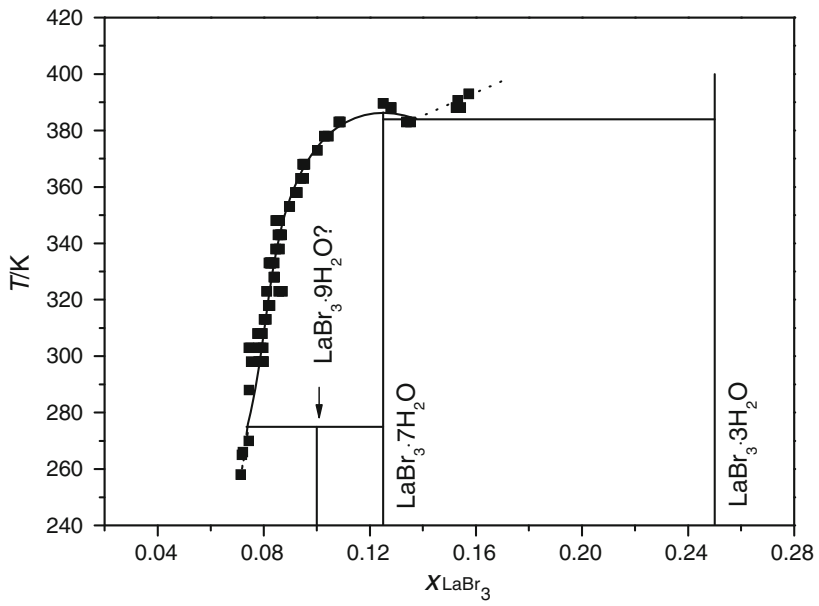

Fig. 3 Water-rich part of the $\mathrm{LaBr}_{3}-\mathrm{H}_{2} \mathrm{O}$ equilibrium phase diagram. Filled squares experimental data shown in Table 2; straight line values calculated by Eq. 5 
whereas $\mathrm{DyI}_{3} \cdot 9 \mathrm{H}_{2} \mathrm{O}, \mathrm{HoI}_{3} \cdot 9 \mathrm{H}_{2} \mathrm{O}, \mathrm{ErI}_{3} \cdot 8 \mathrm{H}_{2} \mathrm{O}, \mathrm{TmI}_{3} \cdot 8 \mathrm{H}_{2} \mathrm{O}$, $\mathrm{YbI}_{3} \cdot 8 \mathrm{H}_{2} \mathrm{O}$, and $\mathrm{LuI}_{3} \cdot 8 \mathrm{H}_{2} \mathrm{O}$ decompose to the anhydrous $\mathrm{LnI}_{3}$ salts in one step according to Heiniö et al. [22]. Crystallographic studies of the hydrates confirmed that they were isostructural: monoclinic $P 2_{1} / n$ for $\mathrm{LnBr}_{3} \cdot 8 \mathrm{H}_{2} \mathrm{O}$ (Ho-Lu), triclinic $P \overline{1}$ for $\mathrm{LnBr}_{3} \cdot 7 \mathrm{H}_{2} \mathrm{O}$ (La-Pr), monoclinic $P 2 / n$ for $\mathrm{LnBr}_{3} \cdot 6 \mathrm{H}_{2} \mathrm{O}$ (Nd-Dy), orthorhombic Pmma for $\mathrm{LnI}_{3} \cdot 9 \mathrm{H}_{2} \mathrm{O}$ (La-Lu), unindexed (probably monoclinic) for $\mathrm{LnI}_{3} \cdot 8 \mathrm{H}_{2} \mathrm{O}$ (Tm-Lu), monoclinic $P 2 / n$ for $\mathrm{LnI}_{3} \cdot 6 \mathrm{H}_{2} \mathrm{O}(\mathrm{La}-\mathrm{Tb})$, and unindexed for $\mathrm{LnI}_{3} \cdot 3 \mathrm{H}_{2} \mathrm{O}(\mathrm{La}-\mathrm{Nd})[10,12,22-24]$. This detailed information is useful for calculation and depiction of the partial $\mathrm{LnBr}_{3}-\mathrm{H}_{2} \mathrm{O}$ and $\mathrm{LnI}_{3}-\mathrm{H}_{2} \mathrm{O}$ phase diagrams. Analogous $\mathrm{Y}$ compounds have the typical structures of other heavy Ln halides; however, Sc compounds are different.

In the case of chlorides, it was possible to draw many of the $\mathrm{LnCl}_{3}-\mathrm{H}_{2} \mathrm{O}$ phase diagrams on the water-rich side. However, in this case, there were sufficient data to construct only the part of the $\mathrm{LaBr}_{3}-\mathrm{H}_{2} \mathrm{O}$ phase diagram depicted in Fig. 3. We are convinced that the rest of the $\mathrm{LaBr}_{3}-\mathrm{H}_{2} \mathrm{O}$ phase diagram is qualitatively similar to the well-known $\mathrm{LaCl}_{3}-\mathrm{H}_{2} \mathrm{O}$ phase diagram [1].

For the design of the $\mathrm{LaBr}_{3}-\mathrm{H}_{2} \mathrm{O}$ equilibrium phase diagram we used the results of the thermogravimetric, DTA, crystallographic, and solubility studies in the extensive temperature range 298-393 K which were supplemented by DSC experiments at lower temperatures. Temperature of the congruently melting $\mathrm{LaBr}_{3} \cdot 7 \mathrm{H}_{2} \mathrm{O}$ was determined to be $389.6 \pm 0.5 \mathrm{~K}$. An example of the DSC run is shown in Fig. 4.

One may easily see that both very asymmetrical exothermic and endothermic peaks, being distant for almost $20 \mathrm{~K}$, are in fact related to the same phase transition because the heat exchanged during the crystallization and melting of $\mathrm{LaBr}_{3}$ is practically the same. The very sharp

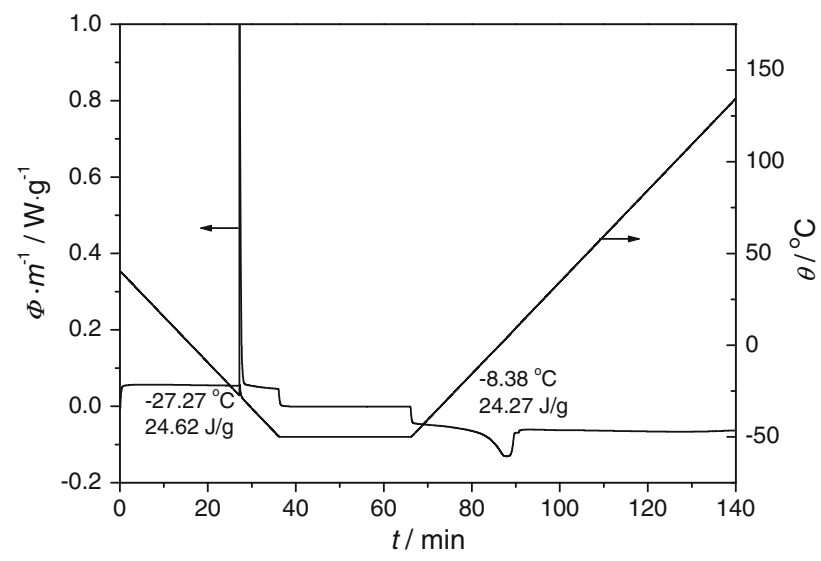

Fig. 4 Differential scanning calorimetry cycle curve (expressed as heat flow divided by sample mass, $\Phi / m$ ) of a mixture of $\mathrm{LaBr}_{3} \cdot 7 \mathrm{H}_{2} \mathrm{O}$ (35.74 mg) and $\mathrm{H}_{2} \mathrm{O}(7.55 \mathrm{mg})$. The experiment was performed on a DSC Q 1000 (TA Instruments) in Ar atmosphere exothermic peak informs us that the crystallization in this system occurs with a significant undercooling effect. This is an additional argument explaining why the experiments with the presented systems are experimentally so difficult. We are continuing investigations at compositions of $\mathrm{LaBr}_{3}$ lower than $0.07 \mathrm{~mol}$ fraction to get more complete information about the water-rich part of this phase diagram. Unfortunately, the phase diagrams of other bromides and iodides still await construction due to the lack of sufficient solubility data at various temperatures, a precise estimation of the composition of the hydrates, and their decomposition temperatures.

\section{Ternary and quaternary aqueous systems}

Many experimental papers were devoted to the aqueous ternary systems of $\mathrm{LnBr}_{3}$ or $\mathrm{LnI}_{3}$ with inorganic and organic compounds as third components. As we mentioned earlier, the solubilities of the majority of bromides or iodides being investigated decreased upon addition of either $\mathrm{HBr}$ or HI. This phenomenon may be treated as the rule. Table 3 shows an example of the decreasing solubility of $\mathrm{LuI}_{3}$ with increasing content of $\mathrm{HI}$ in the solution; the decrease measured was substantial.

Investigations on the ternary systems of $\mathrm{LnBr}_{3}$ with $\mathrm{KBr}$ showed that they display a eutonic-type equilibrium, whereas double salts of general formula $2 \mathrm{LnBr}_{3} \cdot 5 \mathrm{CsBr}$. $n \mathrm{H}_{2} \mathrm{O}$ were formed with $\mathrm{CsBr}$; the double salts were also formed in the presence of $\mathrm{HBr}$ as the fourth component. Neither $\mathrm{NaI}, \mathrm{KI}, \mathrm{NH}_{4} \mathrm{I}$, nor RbI formed double salts with $\mathrm{LnI}_{3}$ in the aqueous ternary systems. When $\mathrm{I}_{2}$ was present in $\mathrm{LnI}_{3}$ solutions then polyiodide ions $\left(\mathrm{I}_{3}{ }^{-}, \mathrm{I}_{5}{ }^{-}\right)$were detected in respective solutions; however, a crystallization of the corresponding polyiodide salts was not observed due to their high solubility [25].

A complete solid miscibility of $\mathrm{LaCl}_{3}$ and $\mathrm{LaBr}_{3}$ heptahydrates was found in the $\mathrm{LaCl}_{3}-\mathrm{LaBr}_{3}-\mathrm{H}_{2} \mathrm{O}$ system. In the investigations of some $\mathrm{LnI}_{3}-\mathrm{Ln}^{\prime} \mathrm{I}_{3}-\mathrm{H}_{2} \mathrm{O}$ systems, a good solid miscibility of both $\mathrm{LnI}_{3} \cdot 9 \mathrm{H}_{2} \mathrm{O}$ and $\mathrm{Ln}^{\prime} \mathrm{I}_{3} \cdot 9 \mathrm{H}_{2} \mathrm{O}$ was observed when differences of the ionic radii of $\mathrm{Ln}$ and $\mathrm{Ln}^{\prime}$ were smaller than 5\%; for larger differences a limited

Table 3 Solubility of $\mathrm{LuI}_{3}$ in aqueous HI solutions at $273 \mathrm{~K}$ [9]

\begin{tabular}{ll}
\hline Concentration of $\mathrm{HI}\left(\mathrm{mol} \mathrm{kg}^{-1}\right)$ & Solubility of $\mathrm{LuI}_{3}\left(\mathrm{~mol} \mathrm{~kg}^{-1}\right)$ \\
\hline 0 & 3.61 \\
3.51 & 2.50 \\
7.29 & 1.40 \\
9.12 & 1.11 \\
12.9 & 0.48 \\
15.3 & 0.33 \\
\hline
\end{tabular}


solid miscibility was observed with sometimes unexplained exclusions [9].

The bromides formed complexes with various organic compounds [9]. Glycine $\left(\mathrm{C}_{2} \mathrm{H}_{5} \mathrm{NO}_{2}\right)$ formed a series of complexes of the formula $\mathrm{LnBr}_{3} \cdot 3 \mathrm{C}_{2} \mathrm{H}_{5} \mathrm{NO}_{2} \cdot 3 \mathrm{H}_{2} \mathrm{O}$. Interaction of $\mathrm{LnBr}_{3}$ with urea and its derivatives (thiourea, acetamide, biuret, acetylurea) was investigated unsystematically; however, some general observations may be formulated. Acetamide, biuret, and acetylurea showed affinity to the bromides resulting in a precipitation of complex compounds, whereas no complexes were identified with thiourea and such systems were of eutonic type. If a complex formation was found with one lanthanide bromide then its analogues were also found for other lanthanide bromides; nevertheless the stoichiometry of such compounds may be changed in the series.

The systems of organic compounds with the iodides [9] were more intensively investigated than with the bromides. All lanthanide iodides formed a complex with urea $\left(\mathrm{CH}_{4} \mathrm{~N}_{2} \mathrm{O}\right)$ of general formula $\mathrm{LnI}_{3} \cdot 5 \mathrm{CH}_{4} \mathrm{~N}_{2} \mathrm{O}$ and this complex with the heavy lanthanides displayed almost constant solubility of $5.6 \pm 0.1 \mathrm{~mol} \mathrm{~kg}^{-1}$, whereas for the light lanthanides the solubility values were scattered irregularly between 4.7 and $8.0 \mathrm{~mol} \mathrm{~kg}^{-1}$. An additional presence of $\mathrm{I}_{2}$ in the system led to the formation of $\mathrm{LnI}_{3} \cdot 4 \mathrm{I}_{2} \cdot 5 \mathrm{CH}_{4} \mathrm{~N}_{2} \mathrm{O}$. $10 \mathrm{H}_{2} \mathrm{O}(\mathrm{La}-\mathrm{Tm})$ or $\mathrm{LuI}_{3} \cdot 3 \mathrm{I}_{2} \cdot 5 \mathrm{CH}_{4} \mathrm{~N}_{2} \mathrm{O} \cdot 7 \mathrm{H}_{2} \mathrm{O}$ [25]. Thiourea $\left(\mathrm{CH}_{4} \mathrm{~N}_{2} \mathrm{~S}\right)$ formed the $\mathrm{LnI}_{3} \cdot 2 \mathrm{CH}_{4} \mathrm{~N}_{2} \mathrm{~S} \cdot 10 \mathrm{H}_{2} \mathrm{O}$ series of compounds and the pertinent solubilities measured were scattered between 3.5 and $6.0 \mathrm{~mol} \mathrm{~kg}^{-1}$, but many of these solubility values were estimated from small figures and may therefore be accurate to only $\pm 0.5 \mathrm{~mol} \mathrm{~kg}^{-1}$. Urotropine hydriodide $\left(\mathrm{C}_{6} \mathrm{H}_{12} \mathrm{~N}_{4} \cdot \mathrm{HI}\right)$ formed $\mathrm{LnI}_{3} \cdot \mathrm{C}_{6} \mathrm{H}_{12} \mathrm{~N}_{4} \cdot \mathrm{HI} \cdot 14 \mathrm{H}_{2} \mathrm{O}$ complexes and biuret $\left(\mathrm{C}_{2} \mathrm{H}_{5} \mathrm{~N}_{3} \mathrm{O}_{2}\right)$ formed $\mathrm{ErI}_{3} \cdot 4 \mathrm{C}_{2} \mathrm{H}_{5} \mathrm{~N}_{3} \mathrm{O}_{2}$; the corresponding solubility results were presented only graphically and could not be precisely evaluated. A quite smooth dependence of solubility ordered according to the atomic number of the lanthanide was displayed by the

Table 4 Solubility of antipyrine complexes $\mathrm{LnI}_{3} \cdot 6 \mathrm{C}_{11} \mathrm{H}_{12} \mathrm{~N}_{2} \mathrm{O}$ in $\mathrm{H}_{2} \mathrm{O}$ at $273 \mathrm{~K}$ [9]

\begin{tabular}{ll}
\hline Starting salt & Solubility $\left(\mathrm{mol} \mathrm{kg}^{-1}\right)$ \\
\hline $\mathrm{LaI}_{3}$ & 0.217 \\
$\mathrm{CeI}_{3}$ & 0.090 \\
$\mathrm{NdI}_{3}$ & 0.070 \\
$\mathrm{SmI}_{3}$ & 0.056 \\
$\mathrm{GdI}_{3}$ & 0.046 \\
$\mathrm{DyI}_{3}$ & 0.047 \\
$\mathrm{ErI}_{3}$ & 0.031 \\
$\mathrm{YbI}_{3}$ & 0.027 \\
$\mathrm{LuI}_{3}$ & 0.024 \\
\hline
\end{tabular}

complexes with antipyrine $\left(\mathrm{C}_{11} \mathrm{H}_{12} \mathrm{~N}_{2} \mathrm{O}\right)$ of general formula $\mathrm{LnI}_{3} \cdot 6 \mathrm{C}_{11} \mathrm{H}_{12} \mathrm{~N}_{2} \mathrm{O}$; the corresponding solubility results are presented in Table 4.

Quite unexpectedly, for these complex compounds we observe much more regular changes of the solubilities than were observed for the simple bromides and iodides.

Acknowledgments This publication was partly based on the literature collected by the late Tomasz Mioduski. The authors are indebted to the IUPAC Subcommittee of Solubility and Equilibrium Data for encouragement during the project preparation. C. G. thanks the University of Warsaw for the financial support (project BST143131).

Open Access This article is distributed under the terms of the Creative Commons Attribution Noncommercial License which permits any noncommercial use, distribution, and reproduction in any medium, provided the original author(s) and source are credited.

\section{References}

1. Mioduski T, Gumiński C, Zeng D (2008) J Phys Chem Ref Data 37:1765

2. Mioduski T, Gumiński C, Zeng D (2009) J Phys Chem Ref Data 38:441

3. Mioduski T, Gumiński C, Zeng D (2009) J Phys Chem Ref Data 38:925

4. Nishimura Y, Iwamoto K, Suzuki Y (1994) Abstracts of the 17th symposium on solution chemistry, Okayama, Japan, p 138

5. Voigt H (1994) Rep. no Vo 511/1-2, Inst Anorg Chem, Bergakademie, Freiberg, Germany (to be published)

6. ZhP Qiao, Chen JG, Zhuo LH, ShSh Zhang (2008) Zh Neorg Khim 53:498

7. Alikberova LYu, Rukk NS, Li V, Stepin BD (1991) Zh Neorg Khim 36:3110

8. LYu Alikberova, AYu Tsitrina, Yastrebova LF, Stepin BD (1974) Zh Neorg Khim 19:284

9. Mioduski T, Gumiński C, Voigt H, Zeng D (2011) J Phys Chem Ref Data (to be published)

10. Boyle TJ, Ottley LAM, Alam TM, Rodriguez MA, Yang P, McIntyre SK (2010) Polyhedron 29:1784

11. Burgess J, Kijowski J (1981) Adv Inorg Chem Radiochem 24:57

12. Lim KC, Skelton BW, White AH (2000) Aust J Chem 53:867

13. Fukushi K, Iwamoto K, Kobayashi K, Ishikawa K, Suzuki Y (1994) J Alloys Compd 207/208:468

14. TSh Sun, Wang FL, Xiao YM (1998) Thermochim Acta 311:21

15. Hohmann E, Bommer H (1941) Z Anorg Chem 248:383

16. Danilenko TV, Emelyanov VI, Venskovskii NU, Ezhov AI (1998) Zh Neorg Khim 43:139

17. Sillen LG, Martell A (1964 and 1971) Stability constants, special publication nos 17 and 25. The Chemical Society, London

18. Gamsjäger H, Lorimer JW, Scharlin P, Shaw DG (2008) Pure Appl Chem 80:233. http://www.iupac.org/publications/pac

19. Lorimer JW, Cohen-Adad R (2003) Thermodynamics of solubility. In: Hefter GT, Tomkins RPT (eds) Experimental determinations of solubilities, chap 1.1. Wiley, Chichester, p 55

20. Gamsjäger H, Lorimer JW, Salomon M, Shaw DG, Tomkins RPT (2010) Pure Appl Chem 82:1137

21. Mayer I, Zolotov S (1965) J Inorg Nucl Chem 27:1905

22. Heiniö O, Leskelä M, Niinistö L (1980) Acta Chim Scand Ser A $34: 207$ 
23. Kwestroo W, Van Hal HAM (1976) J Inorg Nucl Chem 38:1019

24. Junk PC, Semenova LI, Skelton BW, White AH (1999) Aust J Chem 52:531

25. Rukk NS, Savinkina EV, Kravchenko VV, Alikberova DV, Yu L (1997) Russ J Coordin Chem 23:208; Koordin Khim 23:226

26. Alieva ZF, Sulaimankulov K (1981) Spravochnik po Rastvorimosti Karbamidnykh Solevykh Sistem. Mekter, Frunze, p 232
27. Zwietasch KJ, Kirmse EM, Krech I (1984) Z Chem 24:144

28. Zholalieva ZM, Sulaimankulov KS, Ismailov M (1975) Zh Neorg Khim 20:2005

29. Zholalieva ZM, Sulaimankulov K, Ismailov M (1977) FizikoKhimicheskie Izucheniya Soedinenii Metallov z Biologichesko Aktivnymi Veshchestvami. Akademiya Nauk Kirgizkoi SSR, Frunze, p 90 